\title{
Covid-19 Effect on Economic Growth and Employment in Eastern Indonesia Area
}

\author{
MA Djirimu1, Andi Darmawati Tombolotutu ${ }^{2}$, Failur Rahman ${ }^{3}$, Sri Haryani ${ }^{4}$ \\ \{ahlis.djirimu66@gmail.com ${ }^{1}$, itaahlis97@gmail.com² ${ }^{2}$ myfaiels@gmail.com ${ }^{3}$ \} \\ Department of Economics \& Development Studies, Faculty of Economics \& Business, Universitas \\ Tadulako, Jl. Soekarno Hatta KM 9, Tondo, Mantikulore, Palu City, Central Sulawesi $94148^{1,3}$, Faculty \\ of Economics \& Business, Universitas Muhammadiyah Palu, Jl. Jabal Nur No.1, Talise, Mantikulore, \\ Palu City, Central Sulawesi $94118^{2,4}$
}

\begin{abstract}
Covid19.go.id data as of September $2^{\text {nd }}, 2020$ shows that in the Eastern Indonesia Area (EIA), including ten provinces. This increase indicates that the more tracing, testing, and treatment areas, the more case finding increases. Some areas need to be watched out because they experience a false sense of security. This study aims to determine the Covid19 effect on economic growth and employment in the Eastern Indonesia Area that began to be felt in the second quarter of 2020. This paper uses a comparative analysis technique. Relative analysis techniques among provinces in EIA allow this paper to compare the Covid19 effect on economic growth and employment in ten areas in EIA and dissect each region's strategies in overcoming Covid19 transmission and prevention. Comparative techniques are also useful for comparing key factors that can promote and accelerate economic recovery before, during, and after the Covid-19 pandemic.
\end{abstract}

Keywords: covid-19, economic growth, employment.

\section{Introduction}

The Covid-19 cases entered a new phase in mid-June, where the increase reached an average of over 1,000 cases per day. On average, 10 thousand specimens were tested per day, although the numbers were still below the World Health Organization (WHO) standards. The Special Capital District of Jakarta, East Java, and South Sulawesi are the three provinces with the highest Covid-19 cases in Indonesia. Based on data from the Ministry of Health as of June $15^{\text {th }}$ states that in The Special Capital District of Jakarta, the total number of cases reached 9,120 people which represents 23 percent, Covid-19 data cases throughout Indonesia. The second place was followed by East Java with 8,063 cases or 21 percent and South Sulawesi with 2,941 cases or 7 percent. Then West Java with 2,623 cases or 7 percent, Central Java at 6 percent, and South Kalimantan reaching 5 percent of the national Covid-19 cases.

In early September 2020, the Covid-19 task force reported an increase in cases from more than 2,000 to more than 3,000 starting August 27th, 2020 [1]. This condition has not changed relatively. The number of cases in The Special Capital District of Jakarta reached 42,041 cases, or the proportion reached 23.3 percent. Then East Java reached 34,278 cases or 19 percent, and Central Java reached 14,428 cases or 8 percent. The South Sulawesi Province reached 12,194 cases or a proportion of 6.8 percent, followed by South Kalimantan with 8,416 cases or 4.7 percent, and North Sumatra with 7,124 cases or the proportion of 3.92 percent. 
Overall, the proportion of covid19 case findings in these six provinces reached 65.7 percent. West Java is no longer included in the top six of Covid-19. However, we need to observe the Covid19 data from day to day.

Covid19.go.id [1] data as of September $2^{\text {nd }}, 2020$ shows that in the EIA, including ten provinces, Covid19 cases reached 28,946 people, the largest proportion in South Sulawesi reaching 42.13 percent of all cases in EIA. North Sulawesi Province occupies the second position with the findings of covid19 with 3,908 cases and Papua with 3,873 cases. Central Sulawesi Province occupied the lowest position with 245 cases or 0.85 percent. Empirically, this case's findings do not show the actual reality because the case findings depend on whether or not each province has been intensively investigating cases, especially in areas of traditional markets, offices, shopping centers, entertainment centers, ports, and airports.

The Government has issued Law Number 2 of 2020 concerning the Stipulation of Government Regulations instead of Law Number 1 of 2020 concerning State Financial Policy and Financial System Stability for Handling Pandemic of Covid-19 and the Context of Facing a Threat Endangering National Economy and Financial System Stability to Become Law. This regulation aims to take quick, urgent, and extraordinary steps against health problems and in anticipation of saving the economy from worsening conditions. The Government and Bank Indonesia adopted the State Financial Policy, which includes adjusting the National Budget deficit limit, using alternative budget funding sources, adjusting mandatory spending, shifting and refocusing the central and regional budgets, issuing Government Securities programs and loans for additional deficit financing, incentives, and tax facilities, as well as the implementation of the National Economic Recovery Program for the sustainability of the real sector and the financial sector. On the policy side of the financial sector, policy instruments were taken, including expanding the authority of the Financial System Stabilization Committee (FSSC) and the scope of the FSSC meeting, strengthening Bank Indonesia authority, including buying long-term Government Securities in the primary market for handling Covid-19, strengthening the authority of the Financial Services Authority (FSA) and the Indonesia Deposit Insurance Corporation to prevent risks that endanger financial system stability and protect banking customers, strengthen government authority in dealing with banking problems and financial system stability due to the impact of Covid-19.

Covid-19 in Indonesia has made the economy contract in both supply and demand. Strategic sectors in the economy that are vulnerable due to Covid-19 are the tourism sector, including culinary activities, and tourism has stopped impacting 12 million workers. There is a potential for a decline of around 30 percent of the output in this sector in the trade sector and will impact 19.9 million workers. The manufacturing sector, incredibly light and heavy manufacturing such as garments, footwear, automotive, and electronics, experienced demand shocks for export products and luxury goods that threaten more than 8 million workers. The agricultural sector's impact, particularly in the food crop and plantation subsectors, threatens around 29.5 percent of the total national workforce.

Covid-19 with the "severe" category can cause unemployment in 2.92 Indonesians. In the "very severe" scenario, covid-19 could create 5.23 unemployed people, or the open unemployment rate will increase from 5.28 percent in 2019 to 7.33 percent in the severe scenario 9 , respectively. 02 percent in a very demanding scenario. Furthermore, the poverty rate is estimated to increase from 9.41 percent in 2019 to 9.88 percent according to the chubby scenario and 10.98 percent according to the weighty scenario.

At the regional level, data from the Central Statistics Agency shows that of the 15 provinces sampled, namely North Sumatra, West Sumatra, Riau Islands, Lampung, Banten, West Java, Central Java, Bali, South Kalimantan, East Kalimantan, North Sulawesi, Sulawesi 
Central, South Sulawesi, North Maluku, and Papua, only the province of Lampung still shows a positive growth of 2.87 percent because it relies on the agricultural sector. On the other hand, fourteen other provinces experienced a contraction, with the largest contraction in North Sulawesi at -12.48 percent.

On the production side, four provinces experienced an economic contraction in the agricultural sector, namely West Sumatra (-0.69 percent), Bali (-6.14 percent), North Sulawesi (-11.54 percent), Central Sulawesi ( -1.53 percent), and Papua ( -4.72 percent). In the mining and quarrying sector, out of 15 provinces, 13 provinces experienced a contraction, except for Banten and Central Java. In the manufacturing sector, 11 regions experienced a contraction, except North Maluku, Central Sulawesi, East Kalimantan, West Java; Meanwhile, in the transportation and warehousing sectors, the fifteen sample provinces experienced contraction. In the accommodation and food and drink sectors as indicators of the tourism sector's functioning, 11 of the 15 sample areas experienced contraction.

On the expenditure side, during the first quarter of 2020 against the first quarter of 2019, nine regions experienced a contraction in public consumption. Public consumption is the driving force for the regional economy's functioning and is expected to create a backward and forward linkage for the digital food and beverage industry. Besides, government spending contracted in all regions, and Gross Fixed Capital Formation as an indicator of investment in the regions contracted in 13 regions, except for South Kalimantan and North Maluku. On the foreign trade side, exports contracted in twelve regions and imports contracted in eight regions. On a more micro side, the exchange rate of farmers is getting below 100. This means that farmers' welfare decreases, "especially in nineteen provinces, especially South Sumatra, Bali, Central Sulawesi, and South Sulawesi" [2].

The 2020 World Bank study on public spending review in Indonesia in 2020 shows six problems in public spending in Indonesia. First, the limited fiscal space for development resulted from low state revenue collected from taxes and very minimal subsidy spending for the poor. Second, systemic constraints in various economic sectors hinder efforts to improve the quality of spending. Third, there is an inconsistency between planning and budgeting, especially in the budgeting orientation. Fourth, there are challenges in coordination between various government agencies and private institutions. Fifth, there is no performance incentive in fiscal transfers between government agencies. Sixth, the existence of insufficient information systems and constraints involving private participation [3]. Based on the background, the problem is formulated on how covid19 affects EAI's economic growth and employment. This study aimed to analyze the impact of covid19 on economic growth and employment in EIA.

\section{Literature}

A scientific article entitled The Global Macroeconomic Impacts of Covid-19: Seven Scenarios, "written by Warwick Mc Kibbin and Rosen Fernando. Both are from the Australian National University (ANU), the Brookings Institution, and the Primary Research Center for Population Aging (CEPAR). The two authors formulated seven scenarios to measure the global economic impact of Covid19. They use the G-Cubed multi-country model or epidemiological models in economic calculations. The seven scenarios are built based on a historical approach to pandemic events in several countries and several years ago using economic methods that are too technical when described in this article [4] 
First of all, Covid-19 has a significant impact on the job market because of the potential and competitive levels of mortality and morbidity for the population. For China, as the epicenter of covid19, the impact on providing employment has reached an average decline of 15.86 percent. The contagion effect of Covid-19 on average depends on each of the sevencountry scenarios, namely three high categories and three low categories, and one moderate category. The analysis uses a vulnerability Index, which uses three components: the mortality rate due to infection, the morbidity rate due to non-infection, and an increase in morbidity due to the infection's impact on family members. The negative impact of the spread of Covid-19 in other countries beyond health is through human movement transmission through land, air, sea, and trade transportation. This phenomenon is reminiscent of history when the "Black Death" pandemic or black death hit Europe starting in October 1347 after 12 Genoese merchant ships docked at the Port of Messina, the Sicilian Islands spreading bubonic plague which resulted in the loss of a third of Sicily's population.

Second, there is an increase in the cost of doing business in all economic sectors, which disrupts the production network in all countries the United States as the benchmarking of the world's most considerable economic power. The equity risk premium is measured by referring to the components of the population mortality rate and the Country Risk Index. The components of the Country Risk Index include the Governance Risk Index, the Financial Risk Index, and the Health Policy Risk Index. Country Risk Index consists of political, economic, and financial sub-components. Political variables consist of government stability, such as the prevalence of conflict, corruption, and law enforcement. Sub-components of per capita Gross Domestic Product (GDP), real GDP growth rate, and inflation rate are economic variables. Meanwhile, the financial component contains balance sheets of exchange rate stability and international liquidity between countries. The results show that India, China, Indonesia, and other oil and gas producing countries, as well as the rest of the countries, have risk fluctuations in the top 2 compared to other countries that are under two, such as Australia, Brazil, Germany, France, England [5]. Third, the effect on production costs, especially on inputs from the trade, land, sea, and air transportation sectors, is enormous. The seat occupancy rate for air transport has decreased by up to 70 percent despite slashing domestic and international airline prices.

Fourth, the impact on consumption patterns. The decline in the consumption pattern of necessities shifting to a health consumption pattern as a consequence of changes in income and prices, which are eroded by the behavior of "taking a profit" amidst the suffering of other residents affected by Covid-19. Also, the impact of Covid-19 is through the transmission of income and wealth. The pattern of people's behavior directs their income to future savings as a reserve for health anticipation. America's experience shows that during the H5N1 pandemic, Americans' consumption pattern in the economy was affected by 3 percent according to the GCubed model scenario. Economic turmoil in each country and each sector, such as energy, mining, agriculture, durable goods manufacturing, non-durable goods manufacturing, and service sectors. In the energy sector, the most significant impact was on Russia at 54 percent, the mining sector in China reached 50 percent, the agricultural sector in the United States and the rest of the world, the durable manufacturing sector in China and the United States reached 50 percent each, the manufacturing industry sector non-durable in the United States 51 percent followed by China 50 percent, and in the services sector, the enormous impact on the United States at 53 percent followed by China at 50 percent.

Fifth, fluctuation in consumption demand. Of the four scenarios, in the first scenario, the largest decline in consumption demand occurs in the United States by 1.06 times, followed by 
Japan at 1.01 times. In scenario 2, the largest decline in consumption demand is in the United States, reaching 2.66 times.

Sixth, the impact on government spending. Practical experience shows that during the epidemic period, both SARS, MERS, H5N1, there was an increase in the health budget, especially for examinations at airports and seaports. An increase in health infrastructure investment prevents the spread of the pandemic. Scenario 4 shows that a pandemic causes a volatile increase in government spending by 59 percent in the rest of the world, 54 percent in other oil-producing countries, 52 percent in India, 50 percent in China, and 47 percent in Indonesia [6]

Seventh, the increase in the risk premium for all corporations operating in all economic sectors as a consequence of the pandemic's outbreak. The existence of private corporations, State-owned business entities, Regional-owned business entities that require their employees to Work From Home (WFH), work part-time, changing shifts has the consequence of reducing employee salaries, which it is feared will lead to termination of employment if the corporation can no longer cover its fixed costs such as employee salaries lease building, Social Security Agency Labor.

In the end, based on an economic analysis of the effect of the Convid-19 pandemic, it shows that there is an increase in country risk as a consequence of the vulnerability of macroeconomic conditions. In the short term, both the Government and the Central Bank play a significant role in ensuring that the economy disrupted by the pandemic continues to run [7]. The role of the Government in reallocating wasteful spending in Official Travel Warrant, routine activities without measuring, taking the primary duties and functions of fellow Regional Apparatus Organizations, dominant socialization and assessment rather than advocacy and community empowerment, seminars, meetings at the central and other regions rather than field visits in their regions, the development planning discussion (musrenbang) then complacent that its activities have been realized.

The financial system's turmoil was precisely followed by reducing the Bank Indonesia 7 days Reverse Repo Rate (BI7DRR) and a series of 104 trillion IDR Government Securities by Bank Indonesia to safeguard the economy from exposure to market sentiment and moral hazard. Self-quarantine of people under surveillance and patients under surveillance is an effective way to anticipate the arrival of an invisible enemy. Clean and Healthy Lifestyle, according to the findings of Levine and Mc Kibbin, is a highly inexpensive and effective way to anticipate the spread of Covid-19, which erodes social and economic values [4]

Long-term efforts to anticipate the arrival of Covid-19 and its variants are essential for various countries to allocate their state budget for health insurance systems, especially health insurance systems in developing and developing countries where various infectious diseases originate. Global cooperation is an important point that focuses on public health in communities living on one planet earth [8].

Covid-19 has created various kinds of difficult issues to predict an end [5]. These issues include, first, how long will this crisis last? Second, how many workers are affected both temporarily and permanently? Third, how many countries are infected with Covid-19, and how much has the economy declined? Fourth, the effect reaches a peak? Fifth, how much has the economy lost due to Covid-19? Sixth, will the permanent and temporary effects of this crisis continue, and how will the business world organize its forces? Seventh, various public health policies pursued by various countries such as Italy, Taiwan, South Korea, Hong Kong, and China have impacted their economies, such as factory closures, travel restrictions, etc. How do these countries pursue a choice between public health policies and the impact of Covid-19 on the economy? 


\section{Method}

The method used in this paper is descriptive analysis. This paper uses a comparative analysis technique. Comparative analysis techniques among provinces in EIA allow this paper to compare the effect of Covid-19 on economic growth and employment in ten provinces in EIA and dissect each region's strategies in overcoming Covid-19 transmission and prevention. Comparative techniques are also useful for comparing key factors that can promote and accelerate economic recovery before, during, and after the Covid-19 pandemic.

\section{Results and Discussion}

The graph below shows The Covid-19 effect starting to show its impact on the regional economy, starting in the first quarter of 2020. The President announced the existence of Covid-19 on March 2 $2^{\text {nd }}, 2020$.

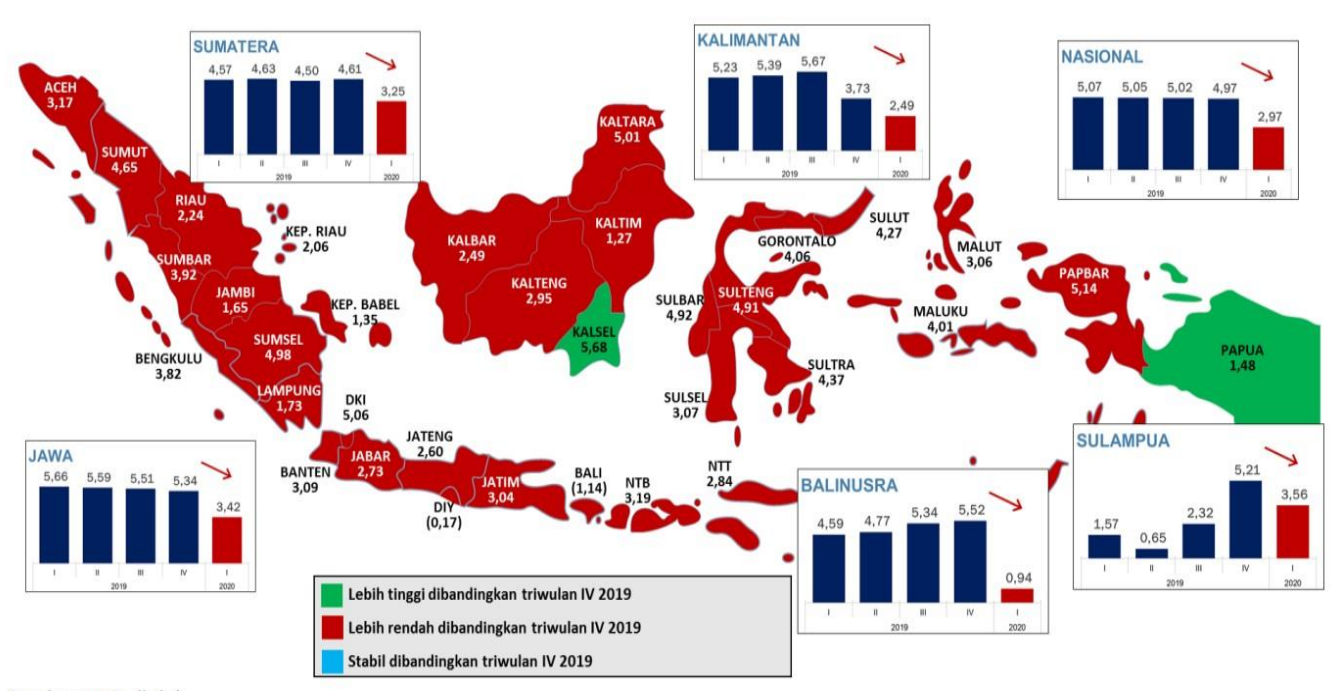

Sumber: BPS, diolah

Fig.1. Covid19 Effect on Regional Economic Performance in First Quarterly 2020

The figure above shows that only two provinces (in green) out of 34 provinces had a higher economic growth rate in the second quarter of 2020 than in the fourth quarter of 2019. In contrast, 32 provinces had a lower economic growth rate in the first quarter of 2020 than in the fourth quarter of 2019. Provinces South Kalimantan and Papua are coal mining areas and gold and copper mines.

Table 1. Economic Growth in Eastern Indonesia Area in 2019-2020 (Percentage)

\begin{tabular}{lccc} 
Description & $2019^{\mathrm{a}}$ & 2020: Before Covid19 & 2020: After Covid19c \\
\hline Sumatera & 4,6 & 4,8 & $-0,3-1,3$
\end{tabular}




\begin{tabular}{lccc} 
Jawa-Bali & 5,5 & 5,4 & $-0,5-0,8$ \\
Nusa Tenggara & 4,5 & 5,9 & $0,0-1,3$ \\
Kalimantan & 5,0 & 6,4 & $-0,4-1,8$ \\
Sulawesi & 6,7 & 6,8 & $-0,5-2,1$ \\
Maluku & 5,8 & 6,1 & $-0,3-1,5$ \\
Papua & $-10,7$ & 6,0 & $0,0-1,6$ \\
\hline
\end{tabular}

Source: a) Statistical Central Agency; b) Target of Government Workplan in 2020; c) National Agency for Development Planning, July 2020.

The existence of Covid-19 affects economic activity in more than 200 countries worldwide. In Indonesia, Large-Scale Social Restrictions has resulted in the stagnation of economic activity, population mobility in the transportation and warehousing sectors, tourism, Government, manufacturing, banking, and non-bank services other economic activities. This is shown by the decline in public consumption activities, especially in the informal sector. The decline in economic activity has resulted in unemployment and increased poverty. The Government is trying to pursue policies through consumption stimulus through social cushioning and business stimulus through Small Medium Enterprises (SMEs) and Ultra Micro (UMi) loans and industrial and State-owned Business Entities business stimulus. Unfortunately, this effort did not produce results in the second quarter of 2020 due to inaccuracies in implementation in the regions and a regulatory bottleneck.

Before Covid-19, the 2020 Government Work Plan target was estimated by the National Agency for Development Planning to reach 6.8 percent as the highest growth rate. Sumatra achieved the lowest growth rate at 4.8 percent. On the other hand, after the Covid-19 pandemic, this growth rate was at a negative interval of 0.5 percent to 2.1 percent in Sulawesi. The heaviest contraction in the economic growth rate was felt in Java due to the concentration of labor-intensive industries in various industrial areas. Meanwhile, in Sumatra, the tourism and oil palm plantation areas will feel the heaviest burden because the development orientation moves towards the food crops and horticulture and fisheries sub-sectors, which will soon be enjoyed short term.

In Kalimantan, the impact of Covid-19 will also be felt, especially in areas where farmers' exchange rate is below 100 points because rational traders will think about reserve for a particular time, the dominant food supply comes from Java and Sulawesi. Kalimantan is an island that relies on dual culture, namely coal and palm. the National Agency for Development Planning estimates Sulawesi to have the highest growth rate of 2.1 percent due to diversification of growth sources, namely the agricultural sector, food crops, horticulture, plantations, animal farming, and agriculture ferronickel base metal mining sector in Southeast Sulawesi and Central Sulawesi Provinces. However, some of the materials are also delivered from North Maluku to become final goods in PT. Indonesia Morowali Industrial Park (PT. IMIP) Industrial Area.

Besides, in Morowali Regency, there is also the PT. Transon Bumindo Resource Industrial Estate and PT. Wanxian Nickle Industry which is operating soon. Apart from being tourism destinations and the trade sector, both North Sulawesi and South Sulawesi play an essential role. According to the National Agency for Development Planning estimates, Maluku and Papua have economic growth of -0.3-1.5 percent and 0.0-1.6 percent. The mining, fisheries, tourism, and agriculture sectors in a broad sense are still the primary sources of growth - the economy. 
Table 2. Covid19 Effect on Eastern Indonesia Area Economy (Percent)

\begin{tabular}{lccccccc}
\hline \multirow{2}{*}{ PROVINCES } & \multicolumn{3}{c}{2019} & & 2019 & \multicolumn{2}{c}{2020} \\
\cline { 2 - 8 } & I & II & III & IV & & I & II \\
\hline SULAWESI & 6,5 & 6,7 & 6,5 & 6,9 & 6,7 & 3,8 & $-1,95$ \\
South Sulawesi & 6,6 & 7,4 & 7,2 & 6,5 & 6,9 & 3,1 & $-3,87$ \\
West Sulawesi & 6,0 & 5,1 & 5,2 & 6,4 & 5,7 & 4,9 & $-1,27$ \\
South East Sulawesi & 6,4 & 6,3 & 6,4 & 6,9 & 6,5 & 4,4 & $-2,39$ \\
Central Sulawesi & 6,5 & 6,3 & 6,2 & 9,6 & 7,2 & 4,9 & $-0,06$ \\
Gorontalo & 6,8 & 6,7 & 5,7 & 6,5 & 6,4 & 4,1 & $-0,27$ \\
North Sulawesi & 6,6 & 5,5 & 5,2 & 5,5 & 5,7 & 4,3 & $-3,89$ \\
MALUKU \& & & - & & & & & \\
PAPUA & $-9,6$ & 13,1 & $-7,4$ & 1,0 & $-7,4$ & 2,9 & 0,72 \\
Maluku & 6,3 & 6,1 & 5,3 & 4,7 & 5,6 & 4,0 & $-0,92$ \\
North Maluku & 7,7 & 7,5 & 4,1 & 5,4 & 6,1 & 3,1 & $-0,16$ \\
Papua & & - & & & & & \\
West Papua & $-18,7$ & 23,9 & $-15,1$ & $-3,7$ & $-15,7$ & 1,5 & 3,45 \\
SULAMPUA & $-0,2$ & $-0,5$ & 2,9 & 8,3 & 2,7 & 5,1 & 0,53 \\
\hline
\end{tabular}

Source: Statistical Central Agency, 2020, data calculated by authors

Table 2 shows the impact of Covid-19 in Eastern Indonesia. In the first quarter of 2020, the impact of covid19 has not been felt. The rate of economic growth still shows a positive trend. The rate of economic growth ranges from the lowest 1.5 percent in Papua Province to 5.1 percent in West Papua Province as the province with the highest economic growth rate in the first quarter of 2020 in EIA. The Covid-19 effect began to be felt in the second quarter of 2020. In that quarter, eight provinces experienced a contraction in economic growth, namely South Sulawesi, West Sulawesi, Southeast Sulawesi, Central Sulawesi, Gorontalo, North Sulawesi, Maluku, and North Maluku. In eight provinces in EIA, the deepest contraction occurred in North Sulawesi, reaching -3.89 percent in the second quarter. On the other hand, a contraction in the economic growth rate was close to zero in Central Sulawesi, reaching -0.06 percent.

EIA's exciting thing is that during the three quarters, namely the first, second, third, fourth quarter, the rate of economic growth contracted respectively -18.7 percent, -23.9 percent, -15.1 percent, and -3.7. Percent. In 2019, the average economic growth rate contracted by -15.7 percent. This contraction impacts the decline in world copper only and is a lesson for regions that rely on regional revenues from the mining sector. Meanwhile, the economy of West Papua Province experienced contraction for two consecutive quarters, namely -0.2 percent in the first quarter of 2019 and -0.5 percent in the second quarter of 2019. This is a lesson for provinces in Sulawesi Island such as Central Sulawesi and Southeast Sulawesi, which the engine of growth in the mining sector is a sector that will not be renewable (non-renewable product). It is never too late for these two provinces to return to the sub-sector of food crops and horticulture, livestock, and fisheries. Sulawesi Island has the potential for post-Covid19 due to sectoral diversification, especially the mainstay of the agricultural sector in a broad 
sense and the potential for sustainable fisheries because the regional economy's future is in rural areas.

The Covid-19 effect on employment in EIA is very clear from data from the Ministry of Manpower in July 2020. In EIA, workers reached 12.54 million people. Of these, 8.02 million people are informal workers or represent 64.01 percent of the total workers. The highest number of workers was in South Sulawesi Province with 3.91 million people, while the lowest number of workers was in West Papua Province with 454 thousand people. The highest proportion of informal workers in absolute terms is South Sulawesi, as much as 2.39 million or 61.11 percent. The largest proportion of informal workers from total workers is in West Sulawesi Province, reaching 72.63 percent in relative terms.

Table 3. The Covid19 Effect on Employment in EIA (person)

\begin{tabular}{lccccc}
\hline \multicolumn{1}{c}{ PROVINCE } & Sent Home & $\begin{array}{c}\text { Work } \\
\text { Termination }\end{array}$ & $\begin{array}{c}\text { Number of } \\
\text { Workers }\end{array}$ & $\begin{array}{c}\text { Informal } \\
\text { Worker }\end{array}$ & $\begin{array}{c}\text { Percentage } \\
\text { Informal } \\
\text { Worker }\end{array}$ \\
\hline South Sulawesi & 17878 & 7089 & 3908181 & 2388319 & 61.11075715 \\
West Sulawesi & 1163 & 426 & 656380 & 476729 & 72.63003138 \\
South East & & & & & \\
Sulawesi & 4393 & 1114 & 1274067 & 804769 & 63.16535944 \\
Central Sulawesi & 5109 & 1500 & 1530259 & 967745 & 63.24060175 \\
Gorontalo & 1176 & 512 & 569166 & 334043 & 58.68990769 \\
North Sulawesi & 2576 & 1275 & 1156826 & 657887 & 56.87000465 \\
Maluku & 4014 & 756 & 697924 & 457838 & 65.59997937 \\
North Maluku & 728 & 383 & 526800 & 324800 & 61.65527715 \\
Papua & 1599 & 611 & 1764113 & 1350781 & 76.56998163 \\
West Papua & 2407 & 2343 & 454136 & 262118 & 57.71795233 \\
EIA & 41043 & 16009 & 12537852 & 8025029 & 64.00641035 \\
\hline
\end{tabular}

An economic recovery strategy can be launched in the EIA by refocusing and reallocating the budget in ten provinces. The people's economic recovery in Papua Province is carried out through two strategies, namely a supply-side-based strategy including the intensification of local taxes and levies, support for the worst-hit economic sectors, and handling of people's businesses and SMEs. The second strategy is handling the demand side of the regional economy. The form of policy instruments undertaken includes maintaining public purchasing power, implementing and synchronizing national and regional social safety nets, and reducing central and regional policy anomalies.

The anti-covid19 economic program launched by the Papua Provincial Government is the Capture Fisheries Production and Development Program, the Export Improvement and Development Program, the Small and Medium Industry Development Program, the Promotion Program, and Investment Cooperation. The social cushioning programs launched are the Housing Development Program, the Empowerment Program for the Poor, Remote Indigenous Communities and Other Persons with Social Welfare Problems, Social Welfare Rehabilitation and Service Programs, Workforce Productivity and Quality Improvement Programs, and Opportunity Enhancement Programs Work. The strategy above will deal with various issues 
that arise in the community in the form of the need to improve data on Social Assistance recipients, Synchronization of interventions between levels of Government in handling, Covid-19 swab test costs, corona cluster data in offices, budget allocation for handling Covid19, transparency of handling budgets Covid-19.

In West Papua Province, the Government has allocated IDR 90.13 billion or 45.56 percent for health care, IDR 48.66 billion for the Social Safety Net or the proportion reaches 24.60 percent, the allocation of economic assistance (post-employment) reaches IDR 54.60 billion or the proportion of 27.60 percent, and the allocation of secretariat support reaching Rp.4.4 billion or the proportion reaching 2.24 percent. West Papua Province is undergoing four phases towards post-Covid-19 recovery, namely the pre-disaster phase, the emergency response phase, the emergency transition phase to recovery, which is currently underway, and the post-disaster phase (new normal). In the second quarter of 2020, West Papua Province became one of the two provinces in Indonesia besides Papua that experienced positive growth, including economic growth in the first semester of 2020. However, the unemployment rate increased at a time when poverty and inequality decreased.

In North Maluku Province, Covid-19 raises various problems in macroeconomics that impact the economic slowdown. First, there are layoffs in the mining, hospitality, trade, transportation, or loss of jobs in the Ministry of Micro, Small \& Medium Enterprises (MSME) sector. Second, local governments do not have a disaster policy scheme. Third, refocusing was carried out massively; spending was stuck in the banking sector, resulting in restrained household consumption.

The North Maluku Provincial Government has taken a policy, namely, first, Large-Scale Social Restrictions to prevent the spread of Covid-19. Second, the Provincial Government activates Chasan Bousori's Hospital as a Covid-19 Hospital, amidst the uncertainty over the end of handling Covid-19. Third, the Provincial Government encourages the Municipal Government of Ternate to prepare a Regional General Hospital Ternate by utilizing the ExMayor's Office as Ternate Hospital. Fourth, the North Maluku Provincial Government in implementing recovery programs and activities is still hampered by a complicated and convoluted budget disbursement mechanism that does not comply with the applicable Government Accounting Standards. Therefore it needs to be simplified with a certainty of spending by Regional Apparatus Organization and certainty availability of liquidity. Fifth, the policy to determine the implementation of Selection of Tilawatil Qur'an for 2021, which was set in North Maluku, so that the financing is handed over to the Central Government so that the Provincial Government of North Maluku can focus on economic recovery after Covid-19 in North Maluku Province. Sixth, the program for handling Covid-19 and economic recovery through the industrial Corporate Social Responsibility (CSR) program in North Maluku Province is carried out in an integrated manner with the economic recovery program prepared by the provincial Government.

We recommend that the post-Covid-19 SMEs recovery program be carried out first, identifying and mapping SMEs' actors affected by covid19. Second, designing a roadmap for developing SMEs according to the characteristics and diagnosis of the problem. Third, digitizing SMEs and traditional markets through cooperation with the Government and the private sector. Fourth, impose tax breaks (Motor Vehicle Tax, Land and Building Tax, Hotel Tax, Restaurant Tax) and Market retribution for SMEs, through tax exemptions for the next three years to recover business after Covid-19. Fifth, facilitate the management of building construction permits for SMEs players so that they can meet the requirements for accessing People's Business Credit in North Maluku Province. Sixth, reactivating the Central Government Program through the Sky Toll across the islands and regions of North Maluku to 
implement online education, online inter-island markets, and support for digitizing SMEs and business actors in the community and village government.

The Maluku Provincial Government is refocusing and reallocating the 2020 Local Budget of IDR 177.66 billion. Of this total, health management allocation reached IDR 131.68 billion, or a proportion of 74.12 percent. Meanwhile, of these other amounts, the economic recovery allocation reached IDR 27.9 billion or the proportion of 15.70 percent, and the allocation for the social safety net reached IDR 18.08 billion or the proportion of 10.18 percent.Local Budget refocusing and reallocation, rationalizing spending on goods and services by at least 50 percent. Besides, the rationalization of capital expenditures of at least 50 percent is used for spending in the health sector and other matters related to health in the context of preventing Covid-19, including the provision of personal protective equipment for medical personnel, facilities, and service equipment for the community, and handling Covid-19 patients; The provision of social safety nets, among others, through the provision of social assistance to the underprivileged poor who have decreased their purchasing power due to the Covid-19 pandemic; and handling of economic impacts, especially keeping the regional business world alive, among others, through empowering micro, small and medium enterprises, as well as cooperatives in the framework of restoring and stimulating economic activity in the regions.

North Sulawesi Province has prepared IDR 521 billion for handling Covid19. Of this amount, IDR 96.5 billion is allocated for health spending such as ventilators, emergency stretchers, disinfectant booths, Personal Protective Equipment (PPE), rapid tests, isolation rooms, disinfectants, alcohol, vitamins, medicines, support for the Covid-19 task force. It is amounting to IDR 50.5 billion. Apart from the health sector, the Provincial Government of North Sulawesi has allocated IDR 45.5 billion for social assistance and a Social Safety Net distributed to 15 districts/cities. Currently, the assistance that has been distributed has reached 47,001 packages of staple foods that have been distributed to all districts/cities. North Sulawesi Province has implemented three strategies: first, the economic recovery strategy, especially the leading sectors. This strategy includes Recovery and Sustainability of Cooperatives and SMEs through credit restructuring and additional capital stimulus and others, development of Food Security through optimizing the development of the agricultural sector (including fisheries and livestock), Recovery Strategy and other business sustainability including traditional markets, market semi-modern, modern market, restaurant/restaurant and inn/hotel with standard health protocol.

The second strategy is to restore social safety nets by updating data based on the Social Welfare Integrated Data to identify affected people for social assistance, developing the effectiveness of Social Safety Net assistance through integrated planning and budgeting between the National Provincial District/City-Village/Village Governments. The third strategy, health recovery strategy, through efforts to meet the needs of Health Workers (doctors, nurses, and other health workers) in the handling of covid19 and non-covid19 patients in hospitals, health center, and open houses, efforts to fulfill infrastructure and facilities in handling patients covid19 and non-covid19 in hospitals, health center, and open houses, efforts to provide adequate shelters in all districts and cities, as well as preventive and promotive health development efforts.

Central Sulawesi Province faced various challenges during the Covid-19 pandemic. First, the distribution of production results was delayed due to the Regulation of the Indonesian Minister of Transportation related to land restrictions, sea and air transportation. Besides, there are several finished goods processing factories that have closed their businesses, resulting in an accumulation of production results. Second, 28 companies reduce the number of 
employees. Based on reports, 1,430 employees have been sent home during the Covid-19 pandemic. Regional income from this sector in the form of regional revenue retribution has been reduced by IDR 750,000,000. Third, there are 1,426 industries affected by the Covid-19 pandemic, especially Small and Medium Industries in Central Sulawesi. Based on data from districts/cities, there are 3,186 workers affected by Covid-19. The strategy pursued is based on three treatment categories (handling health, economy, and social safety nets) as of July $31^{\text {st }}$, 2020, namely efforts to synchronize central/ provincial/district/city interventions in handling Covid19.

Furthermore, the adjustment and implementation of health protocols in the New Normal Era. Collaboration of intra (government-non-government stakeholders in one region) and inter-regional (inter-regional cooperation) in handling Covid-19. Regional specific initiatives in handling Covid-19 by regions. Regional monitoring and evaluation framework in the policy for handling Covid-19 and supporting regulations and why they are needed. The problems faced in handling covid19 are planning, implementation, regulation, stakeholder involvement, and other aspects.

According to Needs Through a Phase I shift of budget cuts for official travel and activities that collect large numbers of people 50 percent of the Regional Apparatus Organizations budget of IDR $112,816,638,596.81,-$. The policy taken is refocusing the 2020 Local budget to support the handling of Covid-19, strengthening social safety nets, and economic recovery; Strengthening safeguarding (monitoring, control, and evaluation) of the implementation of policies on handling Covid-19 including health management, strengthening social safety nets and economic recovery so that it remains transparent, accountable, efficient and effective; Determination of proposed 2021 activities that truly support national priorities in the Government Workplan 2021, have leverage for regional economic recovery, and promote economic transformation; Strengthening the synergy of activities financed from the National Budget, Local Budget, Regional Transfer Funds, Village Funds, private investment, and other funding sources.

The Provincial Government of South Sulawesi has allocated IDR 112.85 billion to refocus and reallocate 2020 local budget funds. Of this amount, IDR 88.05 billion or 71.33 percent is allocated for handling health and safety. The rest is allocated for a Social Safety Net (JPS). Meanwhile, other allocations, such as SMEs venture capital stimulus, tax reduction, and exemption incentives, revolving fund timing incentives, were eliminated. The South Sulawesi Provincial Government has pursued a strategy of improving and maintaining public health quality in a promotional, preventive, and curative manner amid the Pandemic and PostCovid-19 Pandemic.

The second strategy is to improve the quality and access to education that is and equitable as well as the useful link and match between the vocational education process and the development of the business world and industry; The third strategy, encouraging the growth and development of SMEs, the role of cooperatives in the regional economy and the role of Village-Owned Enterprises in maintaining economic stability at the village level; The fourth strategy is to improve the quality and productivity of the workforce based on skills and competencies of the workforce; The fifth strategy is to increase the provision of facilities and infrastructure for the agricultural, plantation, forestry, and aquaculture and fishery sectors through the provision of hygienic fishing and auction technology facilities and the provision of added value to the production of internal resources; The sixth strategy, improving the quality and availability of regional infrastructure, and encouraging labour-intensive programs that are in accordance with the authorities and systems of procurement of goods and services of government agencies; The seventh strategy, optimizing the economic potential of the islands, 
through the provision of supporting infrastructure including means of transportation, boat moorings, clean water facilities, and development of electricity based on natural resource potential, and the development of SMEs of island communities; The eighth strategy, expanding cooperation and partnerships in investment, promotion, marketing. The ninth strategy is to increase the productivity of the regional economy based on natural resources, which is supported by adequate human resources; The tenth strategy, optimizing the prevention, countermeasures, and restoration of environmental damage; The eleventh strategy is to improve adaptation and mitigation capacity to climate change and optimize emergency response to potential natural and non-natural disasters; as well as the twelfth strategy, improving the quality of local government administration and public services.

The Southeast Sulawesi Provincial Government has allocated IDR 400 billion to refocus and reallocate the 2020 APBD for post-Covid-19 handling and recovery. Of this amount, IDR 421.52 billion was allocated for the economic handling of IDR 126.94 billion, handling the economic impact of IDR 60.79 billion, and providing a social safety net (JPS) of IDR 53.78 billion. Another portion of IDR 400 billion, namely Unexpected Expenditures, which reached IDR 158.48 billion, is allocated for 17 Regional Apparatus Organizations that carry out activities to handle covid19, and operational costs for task forces/task forces to accelerate the handling of Covid-19.

Various problems faced by the Provincial Government of Southeast Sulawesi, namely not all Regional Apparatus conducted a review/consultation with Government Internal Control Apparatus before the implementation of activities so that they could be supervised by the Supervision Team (Southeast Sulawesi Governor's Decision Letter Number 274/2020); There are a number of Regional Apparatus that do not carry out optimal coordination in the implementation of activities so that they appear not transparent; Activity reporting by each Regional Apparatus is not optimal; There are delays in carrying out activities and even cancellations of activities are caused by relevance to Regional Apparatus Organisation primary duties or not fulfilling administrative requirements (Decision Letter Management, Cost Budgeting Detail, Standard Operational Procedure, Terms of Reference and implementation methods); Delays in regional apparatus in post-implementation reporting causes the recapitulation of activity reporting to be hampered; data on social assistance recipients is not accurate.

The solution to the various problems above is carried out through two strategies: the first strategy to supervise the implementation of activities resulting from refocusing on handling covid19. The Governor of Southeast Sulawesi establishes an Assistance Team for Planning and Implementation of the 2020 Local Budget Results and Reallocation Activities for Prevention and Handling of Covid-19. The second strategy is to synchronize the handling of Covid-19 between the Central and Provincial Governments: Synchronization of Covid-19 handling activities between the Central Government and the Provincial Government is carried out by following up on policies issued by the Central Government following provincial authorities, including: - Establishment of a covid19 Handling Task Force Covid-19 Provincial Level; - Refocusing activities and budget reallocation as well as revising the 2020 Local Budegt; - Following up on the results of facilitation by the Ministry of Home Affairs regarding the preparation of the 2020 Revised Regional Development Work Plans by prioritizing activities for handling Covid-19; - Consultation with Ministries/Agencies regarding the acceleration of handling Covid-19.

Central and District/City Governments: Synchronization of Covid-19 handling activities between the Central Government and Regency/City Governments is carried out by following up on policies issued by the Central Government following district/city authorities, including: 
- Establishment of a Regency Level Covid-19 Handling Task Force /City; - Refocusing activities and budget reallocation as well as revising the 2020 Local Budget; - Consultation with Ministries/Agencies regarding the acceleration of handling Covid-19. Synchronization of Provinces and Regencies / Cities: - Following up on the results of the facilitation of the 2020 Amendment Regional Development Work Plan by prioritizing activities for handling Covid19; - Consultation and evaluation meetings between the Provincial Government and District / City Governments (at the level of the Regional Head and related Regional Officials) to accelerate the handling of Covid-19.

The Provincial Government of Gorontalo pursued a policy of entering the New Normal period. The Governor of Gorontalo issued Gorontalo Governor Regulation Number 23 of 2020, dated June $14^{\text {th }}$, 2020, concerning Guidelines for Disciplining Protocols for the Prevention and Control of Corona Virus Disease Towards a New Normal Order in Gorontalo Province. Besides, the Provincial Government of Gorontalo is following up on the Circular of the Chief Executive of the Task Force for the Acceleration of Handling of Corona Virus Disease 2019 Number 7 of 2020 concerning Criteria and Requirements for People Travel.

During the Covid-19 Productive and Safe Community Activity Period, to prevent and decide The chain of the spread of covid2019 which has the potential to occur as a result of people's travel into the Gorontalo Province is enforced: -Every traveler who enters Gorontalo Province must have an Entry Permit (SIM) with the requirements that he must have Rapid Test Results. The issuance of an entry permit (SIM) uses the "Around Us" application, which can be downloaded and activated on a mobile phone, to monitor the movement of everyone entering the Gorontalo Province. Besides, the Governor of Gorontalo issued Gorontalo Governor Regulation Number 41 of 2020 dated August 17th, 2020, concerning the Implementation of Discipline and Law Enforcement of Health Protocols as Efforts to Prevent and Covid-2019.

On the academic side, several recommendations deserve attention; first, the Covid-19 pandemic and social restrictions have had a broad impact on various business sectors (transportation, SMEs supporting the digitalization system, and tourism). Business actors in this field need to be invited to dialogue by the local Government to gather detailed information on their problems. If necessary, the method is to optimize the public institutions to intervene in the right types of policies to accelerate recovery from economic downturns. Second, Covid-19 will increase the number of poverty and unemployment numbers, especially in impacting sectors (transportation, SMEs supporting the digitalization system, and tourism).

There is nothing wrong with it. It is a moral obligation for the Government to provide capital assistance for SME business actors, bringing forth labor-intensive development policies for workers in the transportation sector and the tourism sector who have lost their jobs. Third, although social restrictions are no longer officially extended by the Government, the spread of Covid-19 is still ongoing. Even if Gorontalo is still a red zone, social restrictions are consciously needed from the community itself. This will impact the economic activities of the community, mostly day laborers and casual workers, which will worsen the amount of poverty.

In West Sulawesi Province, the most significant impact of Covid-19 in West Sulawesi Province comes from a decrease in household consumption in line with social restrictions implemented to reduce the spread of the virus. Another effect will come from a decrease in foreign and domestic tourists in line with the flight ban. Decreasing export demand for goods from West Sulawesi will also affect economic activity in West Sulawesi. Besides, various economic, social, and health impacts appear. First, the number of small-medium industries (SMIs) affected is 8,738 SMIs, with 661 workers being in work termination, potential losses 
of 28 billion. A total of 816 SMEs and 64 cooperatives with 135 workers/cooperative members affected by covid19 A total of 1,266 workers were dismissed/ laid off from the hospitality sector, restaurants, SMEs, and industry. Second, there are changes and shifts in plans that will impact the development target (Target of Local Medium-Term Plans). Third, limited health infrastructure in handling Covid-19, Referral Hospitals for handling Covid-19 are only in Mamuju and Polewali Mandar. Fourth, poverty in 2020 in the medium scenario is estimated at 11.20 percent or 157,900 people, and the severe scenario is 12.40 percent or 174,250 people. Fifth, the Work from Home Policy (WFH) requires us to develop science and technology in the regions.

The strategy adopted by the Provincial Government of West Sulawesi is first, to increase the efficiency of the allocation of health spending for basic things. The second strategy is implementing the right policies in budget allocation in West Sulawesi. The third strategy is to fight for the special economic zone in West Sulawesi. The fourth strategy is to identify and strengthen leading sectors to curb economic contraction. The fifth strategy maps the current situation and condition of the education sector in West Sulawesi using an online learning model. The sixth strategy is to study the gap between the need and availability of education that involves partnerships or cooperation with external parties who care about the education sector. The sixth strategy is to improve social safety net recovery strategies such as reforming data on economic actors through improving the accuracy of data on economic actors (SMEs) and households that receive assistance, providing assistance focused on impoverished and near-poor families, providing provision for economic actors to adapt and reduce the impact of the Covid-19 pandemic. It is necessary to have a healthy recovery strategy, such as increasing the efficient allocation of health spending for basic things.

\section{Conclusions}

Based on the results of the analysis in the discussion, conclusions and policy recommendations can be drawn as follows. In EIA, the number of confirmed cases experienced an increasing trend from 72 cases to 15,242 cases between the first quarter of 2020 and the second quarter of 2020, or an increase of 21,069.44 percent. Meanwhile, between the second quarter and the third quarter of 2020, confirmed cases of covid19 from 15,242 cases to 79,566 cases or an increase of 422.02 percent. This shows that the ten provinces in EIA should be aware of this increasing trend because the peak of covid19 is not yet known. This increase indicates that the more tracing, testing, and treatment areas, the more case finding increases. Some areas need to be watched out for because they experience a false sense of security or a false sense of security, especially case findings originating from people without symptoms. The impact of covid19 in EIA on economic growth began to be felt in the second quarter of 2020. However, Papua and West Papua Provinces have not experienced a contraction like the other eight provinces in EIA. The Covid-19 effect on employment in EIA also began to be felt in the second quarter of 2020, to be precise, starting in April 2020. Until July 2020, data from the Ministry of Manpower showed that there was a phenomenon of laying off workers reaching 41,043 people in EIA, or the proportion reached 0.327 percent of $12,537,852$ workers. Meanwhile, workers who experienced employment termination reached 16,009 people, or the proportion reached 0.13 percent. The economic crisis experience shows that the informal sector becomes a social safety net such as the SMEs and rural sectors. However, this time the pandemic has made the informal sector experience sluggishness in 
EIA, whose burden is getting heavier because it accommodates 64 percent of the total workers in EIA or reaches 8,025,029 people.

\section{References}

[1] Peta Sebaran [Internet]. 2020. Available from: https://covid19.go.id/Peta-sebaran

[2] Wiku A. Perkembangan Penanganan Covid-19 di Indonesia. 2020.

[3] The World Bank. Indonesia Economic Prospects :The Long Road To Recovery [Internet]. 2020. Available from: http://hdl.handle.net/10986/34123

[4] McKibbin WJ, Fernando R. Global Macroeconomic Scenarios of the COVID-19 Pandemic. SSRN Electron J. 2020;

[5] Jackson J, Weiss M, Schwarzenberg A, Nelson R. Global Economic Effects of COVID-19. Congr Res Serv [Internet]. 2020;(20):78. Available from: https://crsreports.congress.gov

[6] Hsiang S, Allen D, Annan-Phan S, Bell K, Bolliger I, Chong T, et al. The effect of large-scale anti-contagion policies on the COVID-19 pandemic. Nature [Internet]. 2020;584(7820):262-7. Available from: http://dx.doi.org/10.1038/s41586-020-2404-8

[7] Peckham R. Economies of contagion: Financial crisis and pandemic. Econ Soc. 2013;42(2):226-48.

[8] Guerrieri, Veronica; Lorenzoni, Guido; Straub, Ludwig; Werning I. Macroeconomic Implications of COVID-19: Can Negative Supply Shocks Cause Demand Shortages? SSRN Electron J [Internet]. 2020;1-36. Available from: https://doi.org/10.2139/ssrn.3570096 